Research Journal of Applied Sciences 5 (6): 376-382, 2010

ISSN: $1815-932 \mathrm{X}$

(C) Medwell Journals, 2010

\title{
Biohydrogen Production by Anaerobic Biofilms from a Pretreated Mixed Microflora
}

\author{
Ileana M.M. Moreno-Davila, Leopoldo J. Rios-Gonzalez, Jose G. Gaona-Lozano, \\ Yolanda Garza-Garcia, Jose A. Rodriguez-de la Garza and Jesus Rodriguez-Martínez \\ Department of Biotechnology, Universidad Autonoma de Coahuila, Saltillo, Coahuila, Mexico
}

\begin{abstract}
The present research focused on fermentative production of hydrogen by anaerobic biofilms from a pretreated mixed microflora in a continuous fixed bed-reactor. Microbial mixed culture was thermally $\left(100^{\circ} \mathrm{C}\right.$, by $30 \mathrm{~min})$ and acidic $(\mathrm{pH} 3.0,24 \mathrm{~h})$ pretreated. Metagenomic analysis of the pretreated microbial cultured was conducted. Microbial cultured community was mainly formed by lactic acid bacillus from Phylum firmicutes. Dairy wastewater (COD $27.73 \mathrm{~g} \mathrm{~L}^{-1}, \mathrm{pH} 11.3$ ) at a temperature of $18 \pm 5^{\circ} \mathrm{C}$ was fed to a $1.5 \mathrm{~L}$ continuous fixed bed-reactor using Opuntia imbricata as substratum. Results obtained showed that at an HRT of $0.4 \mathrm{~h}$ the yield hydrogen production was $2.11 \mathrm{mmol} \mathrm{H}_{2} \mathrm{~g}^{-1} \mathrm{COD}_{\text {conameds }}$ mean while an increase in $\mathrm{HRT}$ to $0.8 \mathrm{~h}$ caused a decrease in yield hydrogen production to $1.31 \mathrm{mmol} \mathrm{H}_{2} \mathrm{~g}^{-1} \mathrm{COD}_{\text {consumed }}$.
\end{abstract}

Key words: Fuel, hydrogen, metagenomic, Opuntia imbricata, dairy wastewater, firmicutes

\section{INTRODUCTION}

As a consequence of industrial development and population growth there has been an increase of 17 fold in the last century of energy consumption in the world. However, conventional energy resources like fossil fuels cannot meet the increasing energy demand (Nikolic et al., 2009). This excessive usage of fossil fuels has caused a considerable negative environment impact e.g., global warming and acid rain resulting in serious effects on the earth's climate, weather conditions, vegetation and aquatic ecosystems (Alalayah et al., 2008). Therefore, the use of biofuels as alternative energy sources has many advantages such as contribution to the reduction of $\mathrm{CO}_{2}$ emission, lower dependency on the import of oil for non-oil producing countries, new employment opportunities and development of rural communities they are easily available from common biomass sources, biodegradable and contribute to the sustainability (Wang et al., 2009a, b).

Hydrogen gas is a clean energy source with a high energy content of $122 \mathrm{~kJ} \mathrm{~g}^{-1}$. Unlike fossil fuels hydrogen does not cause any $\mathrm{CO}_{2}, \mathrm{CO}, \mathrm{SO}_{\mathrm{z}}$ and $\mathrm{NO}_{\mathrm{z}}$ emissions and producing water as its only by-product when it burns reducing green house effects considerably (Chong et al., 2009). Hydrogen is considered to be a major energy carrier of the future and can directly be used in fuel cells for electricity generation. However, currently $90 \%$ of $\mathrm{H}_{2}$ is being produced from methane reformation or electrolysis of water and contributes to only $3 \%$ total energy consumption (Sparling et al., 2006). These processes are both energy intensive and not environment-friendly. Biological hydrogen production from renewable resources using microorganisms appears to be the most attractive method compared to other hydrogen production processes because it has fewer environmental concerns. Microorganisms that can produce hydrogen are anaerobes including photosynthetic microorganisms (photo fermentation) and anaerobic bacteria (dark fermentation) (Wang et al., 2009a, b).

Fermentative hydrogen production with anaerobic bacteria is a promising way of economical and sustainable energy source generation (Ren et al., 2009). A dark fermentative hydrogen production process can be conducted by using either pure cultures or mixed cultures. However, in a fermentative hydrogen production process using mixed cultures the seed sludge often needs a pretreatment to suppress as much hydrogen consuming bacterial activity as possible while still preserving the activity of the hydrogen-producing bacteria (Wang and Wan, 2009).

Recently, experiments have been carried out to study the possibility of hydrogen production using organic wastes from various industries in combination with the wastewater treatment strategy (Chong et al., 2009). Food wastewater contains high concentrations of carbohydrates, lipids or peptones favoring bioconversion into hydrogen (Wu and Lin, 2004). Dairy wastewater contains complex organics such as polysaccharides, proteins and lipids which on hydrolysis form sugars,

Corresponding Author: Leopoldo J. Rios-Gonzalez, Department of Biotechnology, Universidad Autonoma de Coahuila, Saltillo, Coahuila, Mexico 
amino acids and fatty acids. In subsequent acidogenic reaction, these intermediate products are converted to Volatile Fatty Acids (VFA) which are further degraded by acetogens forming acetate, $\mathrm{CO}_{2}$ and $\mathrm{H}_{2}$ (Mohan et al., 2007).

The objective of this study was to investigate in a continuous flow fixed bed reactor the process of $\mathrm{H}_{2}$ production from dairy wastewater with an anaerobic pretreated mixed microbial culture for biofilms formation on Opuntia imbricata to develop a stable anaerobic fermentation process for continuous $\mathrm{H}_{2}$ production. Substratum used on this research has been tested to develop biofilm reactor systems useful for the treatment of different wastewaters.

Contrary to some synthetic organic or inorganic polymer materials such as resins, gels and fibers conventionally used as substratum, Opuntia imbricata is renewable with high grade of reusability and without disposal problems (Ilyna et al., 2008). These properties were considered important to asses this material for $\mathrm{H}_{2}$-producing biofilm developing. In addition 16S rDNA sequence analysis from anaerobic mixed cultures were carried out to establish predominant bacterial types that grew in the hydrogen process production in this particular research.

\section{MATERIALS AND METHODS}

Substratum pretreatment and preparation: Small pieces of dried stems of Opuntia imbricata were cut (previously wash and rinse) in segments of $2.5 \pm 0.2 \mathrm{~cm}$ in height and $2.5 \pm 0.5 \mathrm{~cm}$ in diameter (Fig. 1) and their characteristics are shown in Table 1.

Dairy wastewater: Dairy wastewater was collected directly from the company's sewage (Lacticinios Mexicanos, S.A. de C.V) located in Saltillo, Coahuila, Mexico. After recollection wastewater was stored at $4^{\circ} \mathrm{C}$ until characterization. Chemical Oxygen Demand (COD), $\mathrm{pH}$, conductivity, Total Suspended Solids (TSS) was determined according to analytical methods described in APHA/AWWA/WEF (1998) (Table 2).

Pretreatment of anaerobic microbial mixed culture: Anaerobic microbial mixed culture $(500 \mathrm{~mL})$ was obtained from a UASB reactor that treated wastewater from brewery Modelo (Zacatecas, Mexico). Pretreatment was carried out as describe by (Chen and $\mathrm{Hu}, 2007$ ). In the heat pretreatment, the granules or sludge was heated in boiling water bath for a short period of time $(30 \mathrm{~min})$ first then cooled down. Heat pretreatment was followed by acidic

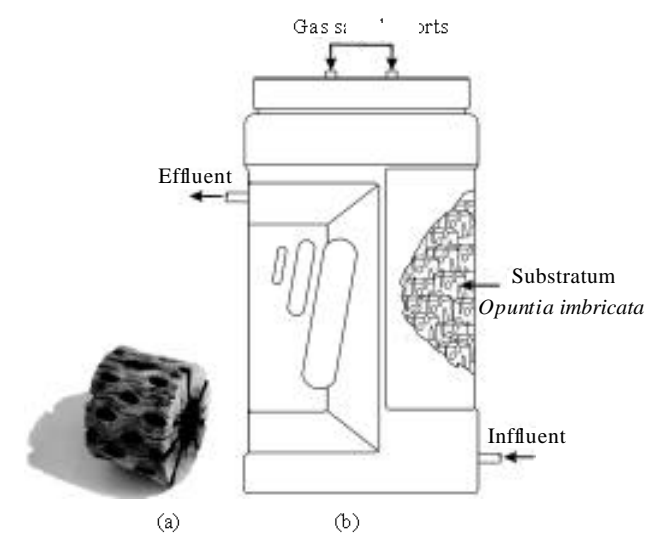

Fig. 1: Continuous fixed bed up-flow reactor packed with Opuntia imbricata used for hydrogen producing biofilm formation

Table 1: Characteristics of substratum

\begin{tabular}{ll}
\hline Parameters & Specification \\
\hline Identification & $\begin{array}{l}\text { Opuntia imbric ata } \\
\text { Configuration }\end{array}$ \\
Origin & $\begin{array}{l}\text { Natural } \\
\text { Height }\end{array}$ \\
Diameter & $2.5 \pm 0.2 \mathrm{~cm}$ \\
Density & $2.5 \pm 0.5 \mathrm{~cm}$ \\
Specific surface area & $0.838 \mathrm{~g} \mathrm{~cm}^{-3}$ \\
& $0.599 \mathrm{~m}^{2} \mathrm{~g}^{-1}$ (from BET) \\
Table 2: Dairy wastewater composition & \\
\hline Parameters & \\
pH & Dairy wastewater \\
COD $\left(\mathrm{g} \mathrm{L}^{-1}\right)$ & $11.32 \pm 0.240$ \\
Conductivity $\left(\mathrm{m} \mathrm{S}^{-1}\right)$ & $27.73 \pm 0.531$ \\
TSS $\left(\mathrm{g} \mathrm{L}^{-1}\right)$ & $2640 \pm 52.8$ \\
& $21.9 \pm 0.557$ \\
\hline
\end{tabular}

pretreatment that involved decreasing the $\mathrm{pH}$ of the sludge or granule solution to 3.0 using $0.1 \mathrm{~N} \mathrm{HCl}$ solution for $24 \mathrm{~h}$ and a readjustment of $\mathrm{pH}$ back to 7.0 by $0.1 \mathrm{~N}$ $\mathrm{NaOH}$ solution.

DNA extraction: Metagenomic DNA extraction from pretreated bacterial source sample was assayed according to the silica-based method proposed by Rojas et al. (2008).

PCR amplification: Universal primers ge338 (forward) (5'-ACTCCTACGGGAGGCAGCAG-3') and gc518 (reverse) ( $5^{\prime}$-ATTACCGCGGCTGCTGG-3') for the domain bacteria were used for amplification of the hypervariable $\mathrm{V} 3$ region on $16 \mathrm{~S}$ rDNA. Both primers included a 40 base GC clamp and produced a $230 \mathrm{pb}$ amplicon to be analyzed by DGGE (Hovda et al., 2007). The PCR reaction mixture $(25 \mu \mathrm{L})$ consisted of $5 \mathrm{mM} \mathrm{MgCl}_{2}, 200 \mu \mathrm{M}$ each dNTP, $0.5 \mu \mathrm{M}$ forward and reverse primers, $2.5 \mathrm{U}$ Taq DNA polymerase (Bioline), 1-5 $\mu \mathrm{L}$ template (approximately $100-200 \mathrm{ng}$ of metagenomic DNA) and $0.3 \%$ bovine serum 
albumin (BSA, Sigma-Aldrich) in a proprietary buffer ( $\mathrm{pH}$ 8.5). All PCR amplifications were performed on a thermal cycler My Cycler (Bio-Rad Laboratories Inc., USA) using a touchdown program. An initial denaturation for $5 \mathrm{~min}$ at $94^{\circ} \mathrm{C}$ was followed by a total of 30 cycles of amplification consisting of denaturation at $94^{\circ} \mathrm{C}$ for $60 \mathrm{sec}$, touchdown annealing (10 cycles from $65-55^{\circ} \mathrm{C}, 1^{\circ} \mathrm{C}$ decrement/cycle; 20 cycles at $55^{\circ} \mathrm{C}$ ) for $45 \mathrm{sec}$ and extension at $72^{\circ} \mathrm{C}$ for $60 \mathrm{sec}$. The program ended with an extension step at $72^{\circ} \mathrm{C}$ for $5 \mathrm{~min}$. PCR products were examined and verified on $2 \%$ agarose gels and visualized by ethidium bromide staining (Sigma-Aldrich). The gels were photographed under UV light in a Bio-Rad GelDoc 2000 system (Bio-Rad Laboratories Inc., USA).

DGGE analysis: Denaturing gradient gel electrophoresis was performed with the DCode ${ }^{\mathrm{TM}}$ (Bio-Rad Laboratories Inc., USA) system and reagents from Sigma-Aldrich. Denaturation conditions were optimized based on preliminary results but generally, gels had denaturation gradients of $40-60 \%$ where $100 \%$ denaturant is defined as $7 \mathrm{M}$ urea and 40\% formamide. Gels were either $8 \%$ polyacrylamide or contained an $8-12 \%$ polyacrylamide gradient. Electrophoresis was at $60 \mathrm{~V}$ for $16 \mathrm{~h}$. Gels were stained with Sybr $\backslash$ Gold (Invitrogen). Bands in DGGE images were identified visually on a presence-absence basis. PCR products were directly sequenced by an external sequencing service (Macrogen, USA) with the same primers used for amplification. Contig assembling and sequence alignment was performed with the free software BioEdit (Hall, 2005) and taxonomic classification and nearest neighbors with the RDP database (release 91) (Maidak et al., 2001; Cole et al., 2005). The RDP classifier uses a naive Bayesian method (Wang et al., 2007). Phylogenetic inference based on 16S rRNA gene sequences was carried out following the maximum parsimony method by using bootstrap values based on 100 replications with program Winclada (Nixon, 1999).

Biofilm formation on Opuntia imbricata: Biofilm formation was carried out in a $1.5 \mathrm{~L}$ continuous fixed bed reactor (Fig. 1), $520 \mathrm{~g}$ (dried weight) of Opuntia imbricata (substratum preparation describe previously) was added. Finally $500 \mathrm{~mL}$ of pretreated anaerobic microbial mixed culture was added.

Reactor was fed by a peristaltic pump (Manostat division of Barnant Company, Simon varistaltic pump, USA) for a period of 30 days with following conditions; initial $\mathrm{pH} 7.0$, temperature $20 \pm 3^{\circ} \mathrm{C}$ (ambient temperature), $\mathrm{HRT}=2 \mathrm{~h}$ and initial wastewater concentration was $27.73 \mathrm{~g} \mathrm{COD} \mathrm{L}^{-1}$ maintaining an initial concentration of substrate up to $12 \mathrm{~g} \mathrm{~L}^{-1}$ thus to control a rank of
$\mathrm{pH}$ of $4-5,5$ by means of the effect of the substrate concentration during this period all parameters mentioned above were monitored on daily basis. Subsequently HRT was decreased to $1 \mathrm{~h}$ for a period of 30 days maintaining rest of condition ( $\mathrm{pH}$, temperature and concentration) as mentioned above.

HRT influence on hydrogen production: Two HRT's $(0.4$ and $0.8 \mathrm{~h})$ were assessed for this stage of the research. Dairy wastewater concentration was $27.73 \mathrm{~g} \mathrm{~L}^{-1}$, $\mathrm{pH} 11.32$ and temperature (ambient) $18 \pm 5^{\circ} \mathrm{C}$.

Analysis: The analysis of hydrogen and methane were determined by Gas Chromatography (GC TCD) Varian 3400 , equipped with a Molecular Sieve $5^{\text {a }}$ packed column injecting $25 \mu \mathrm{L}$ using a $1 \mathrm{~mL}$ syringe. GC conditions were as followed injector and detector temperature $200^{\circ} \mathrm{C}$, column temperature $50^{\circ} \mathrm{C}$ using helium as carrier gas with flow rate $6 \mathrm{~mL} \mathrm{~min}{ }^{-1}$. Removal of COD was determined according to analytical methods described by APHA/ AWWA/WEF (1998). The $\mathrm{pH}$ was determined from effluent and measured by potentiometer (WTW, Inolab$\mathrm{pH} / \mathrm{ION}$ Level 2). All data collected represents the means of three replications that were obtained for each experiment.

\section{RESULTS AND DISCUSSION}

Metagenomic analysis of pretreated mixed microbial consortium pretreated: The microbial community of the biofilm used for biohydrogen production was studied by PCR and DGGE analysis of the pretreated mixed microbial consortium. The metagenomic DNA extracted from the consortium had a high molecular weight with a size near to $20 \mathrm{~kb}$ and show scarce evidence of degradation. Molecular analysis using PCR-DGGE followed by sequencing enabled characterization of the bacterial population in the biofilm reactor (Fig. 2a). This approach allows detection of the dominant bacteria present in the samples by sequencing the interesting gel bands (Fig. 2b).

Excised DGGE bands were compared with BLAST references based on the phylogenetic relationship of the $\sim 230$ bp partial $16 \mathrm{~S}$ rDNA sequence of the hypervariable $\mathrm{V} 3$ region. The V3 region is regarded as a good choice when it comes to length and species-species heterogeneity (Coppola et al., 2001; Ercolini, 2004), the region is also considered to be highly variable and have a high grade of resolution. Comparison of the $16 \mathrm{~S}$ rDNA sequences to databases showed most belonged to the Firmicutes phylum being lactic acid bacteria the predominant population in the mixed microbial consortium. These sequences share a high identity to different taxonomic ranks such as Bacillales and Lactobacillales. 


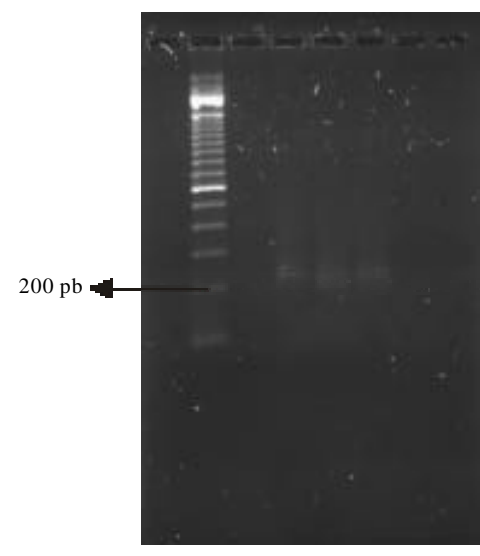

(a)

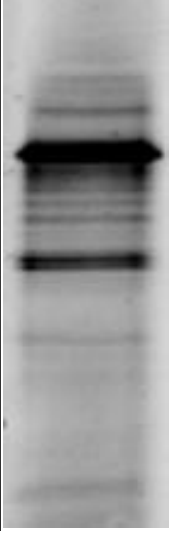

(b)
Fig. 2: a) PCR product amplified with universal primers 318 and gc518; b) DGGE analysis of a pretreated mixed microbial consortium for the fermentative hydrogen production from dairy wastewater. The ${ }_{\mathrm{m}} \mathrm{ADN}$ extracted was PCR amplified using primers gc318/gc518

Recent reports of hydrogen production by microbial mixed culture made same approach by metagenomic analysis (Yang et al., 2007) carried out the $16 \mathrm{~S}$ rDNA analysis of DNA extracted from bioreactors during periods of high $\mathrm{H}_{2}$ production from cheese processing wastewater observing that $>50 \%$ of the bacteria present were members of the genus Lactobacillus and about 5\% were Clostridia (Angelidaki et al., 2008) carried out same analysis for identification of hydrogen producing bacteria from the granules obtained of thermophilic anaerobic reactors $\left(60\right.$ and $\left.70^{\circ} \mathrm{C}\right)$ with different carbon source, they found that Firmicutes phylum had a population density of $15-27 \%$ at $60^{\circ} \mathrm{C}$ and $17-20 \%$ at $70^{\circ} \mathrm{C}$, confirming early reports by Cheong and Hansen (2007) whom mentioned that some species of Bacillus and Clostridium are hydrogen producing bacteria and resistant to high temperatures and desiccation due to formation of spores remaining only microorganisms capable of forming spores and eliminating methanogens that do not posses this capability. Some other research have mentioned the effect of acidic pretreatment on microbial community causing important change on community microbial distribution as mentioned by Hwang et al. (2009) that used FISH method and the LIVE/DEAD cell viability test and observed that after the acid pre-treatment $\left(\mathrm{HCl}, \mathrm{HNO}_{3}\right.$ and $\left.\mathrm{H}_{2} \mathrm{SO}_{4}\right)$, the rate of bio- $\mathrm{H}_{2}$ production increased rapidly and the number of viable cells belonging to Clostridium sp. also increased.

Influence of HRT on hydrogen production in fixed bed up-flow reactor: Hydrogen production on a continuous

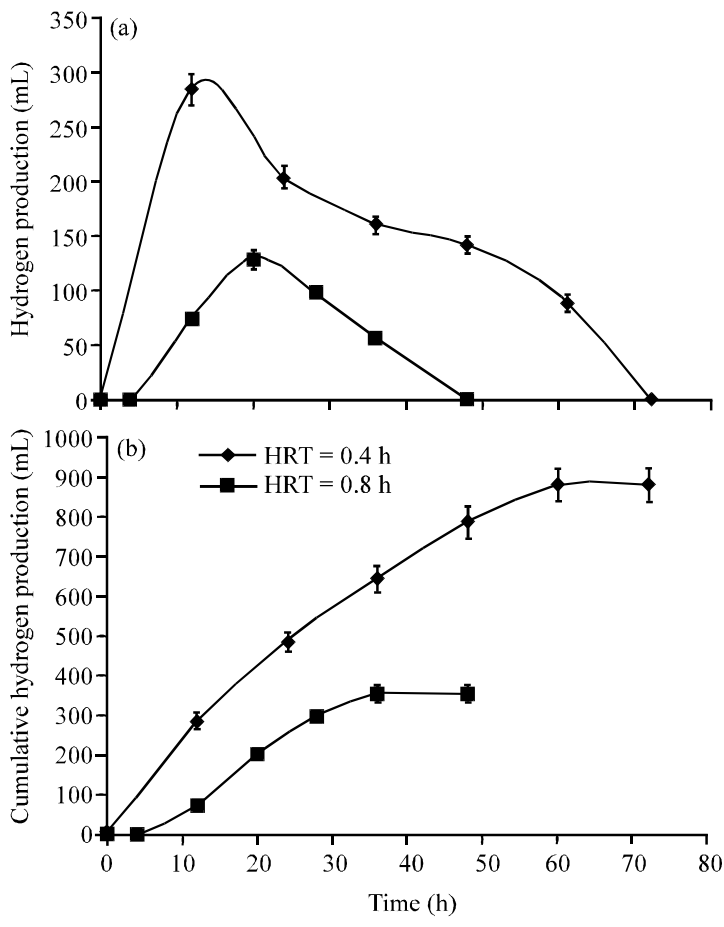

Fig. 3: a) Hydrogen production (mL) and b) cumulative hydrogen production $(\mathrm{mL})$ at different HRT's $(0.4$ y $0.8 \mathrm{~h})$, by a continuous fixed-bed up-flow reactor with Opuntia imbricata as substratum using dairy wastewater (COD $27.73 \mathrm{~g} \mathrm{~L}^{-1}$; initial $\mathrm{pH} 11.32$; temperature $18 \pm 5^{\circ} \mathrm{C}$ )

fixed bed up-flow reactor at different HRT's $(0.8$ and $0.4 \mathrm{~h})$ with initial COD concentration $27.33 \mathrm{gL}^{-1}, \mathrm{pH} 11.32$ at ambient temperature $\left(18 \pm 5^{\circ} \mathrm{C}\right)$ is shown on Fig. 3a. Hydrogen production was higher at HRT of $0.4 \mathrm{~h}$ with maximum of $283 \mathrm{~mL}$ of hydrogen after $12 \mathrm{~h}$ ( 1.2 fold higher than HRT $0.8 \mathrm{~h}$ ) and only $128 \mathrm{~mL}$ of hydrogen after $20 \mathrm{~h}$ for the case of HRT of $0.8 \mathrm{~h}$. Figure $3 \mathrm{~b}$ shows same behavior of cumulative hydrogen production at different HRT's where at HRT of $0.4 \mathrm{~h}$ there was an accumulated production of $880 \mathrm{~mL}$ of hydrogen after $60 \mathrm{~h}$ whereas at HRT of $0.8 \mathrm{~h}$ there was only $353 \mathrm{~mL}$ of hydrogen after $48 \mathrm{~h}$. These differences were reflected directly on hydrogen yield production showing that at an HRT of $0.4 \mathrm{~h}$, hydrogen yield production was $2.11 \mathrm{mmol} \mathrm{H}_{2} \mathrm{~g}^{-1}$ $\mathrm{COD}_{\text {consumed }}$ whereas an increase on HRT caused a drop on hydrogen yield production to $1.31 \mathrm{mmol} \mathrm{H}_{2} \mathrm{~g}^{-1} \mathrm{COD}_{\text {consumed }}$ (Table 3).

Yang et al. (2007) obtained a hydrogen yield production of 1.8-2.3 mmol $\mathrm{H}_{2} \mathrm{~g}^{-1} \mathrm{COD}_{\text {consumed }}$ at an HRT of $24 \mathrm{~h}$ at a $\mathrm{pH}$ range of 4.0-5.0 using synthetic dairy wastewater under mesophilic conditions. Figure 3 a shows a lag phase of $4 \mathrm{~h}$ when an HRT's of $0.8 \mathrm{~h}$ was used this behavior is due to a lower decrease rate of $\mathrm{pH}$ level in the 
Table 3: COD removal (\%) and $\mathrm{H}_{2}$ yield production by a continuous fixed-bed up-flow reactor with Opuntia imbric ata as substratum at different HRT's

\begin{tabular}{lc}
\hline HRT $(\mathrm{h})$ & $\mathrm{H}_{2}$ yield production $\left(\mathrm{mmol} \mathrm{H}_{2} \mathrm{~g}^{-1} \mathrm{COD}_{\text {consumed }}\right)$ \\
\hline 0.4 & 2.11 \\
0.8 & 1.31 \\
\hline
\end{tabular}

$\mathrm{COD}_{\mathrm{c}-\text { Chemical Oxy gen Demand consumed }}$

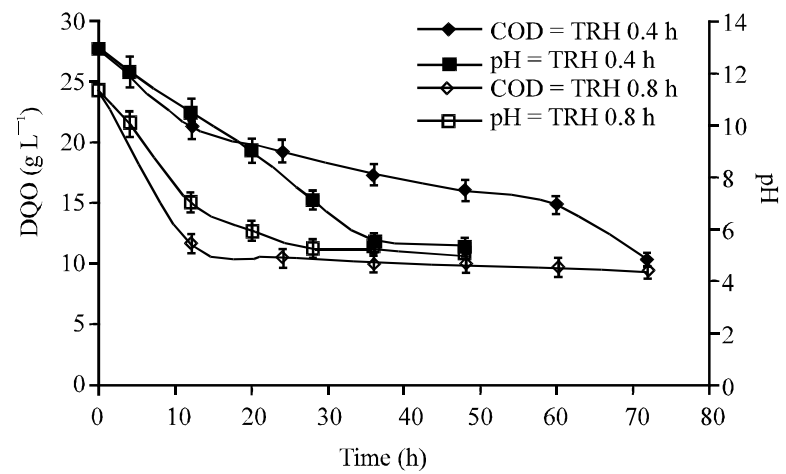

Fig. 4: COD removal and behavior of $\mathrm{pH}$ of the effluent of a continuous fixed-bed up-flow reactor with Opuntia imbricata as substratum at different HRT's $(0.4$ and $0.8 \mathrm{~h})$ using dairy wastewater (COD $27.73 \mathrm{~g} \mathrm{~L}^{-1}$; initial $\mathrm{pH} 11.32$; temperature $\left.18 \pm 5^{\circ} \mathrm{C}\right)$

medium (Fig. 4). Behavior of $\mathrm{pH}$ can be shown in Fig. 4. For HRT of $0.4 \mathrm{~h}$ the decrease rate $\mathrm{pH}$ level was faster, reaching a $\mathrm{pH}$ of 5.4 after $12 \mathrm{~h}$ whereas with a HRT of $0.8 \mathrm{~h}, \mathrm{pH}$ only decreases to 7.01 during the same period of time.

It is mentioned when using a microbial mixed culture and drastic changes on $\mathrm{pH}, \mathrm{HRT}$, temperature and substrate concentration occurs, this can affect the metabolism of hydrogen producing bacteria or a shift on the microbial community can take place, leading to a change in fermentation sub-products and decreasing the hydrogen yield production (Kalia and Purohit, 2008).

Fermentative hydrogen production with microbial mixed culture can take place in a wide range of $\mathrm{pH}$ from 3.3-5.0 (Gadhamshetty et al., 2009) contributing to inhibition of methanogenic bacteria that cannot tolerate $\mathrm{pH}$ below 5 according to different reports (Kim et al., 2003). However, Kim et al. (2003) reported that hydrogenotrophic methanogens can tolerate $\mathrm{pH}$ below 5 but was not the case for acetoclastic methanogens that were completely inhibit. It also mentioned by Kim et al. (2003) that at high HRT's hydrogenotrophic methanogens can tolerate acidic conditions more than other methanogens groups. Chen et al. (2001) reported a slight methanogenic activity under high dilution rates conditions (HRT of $1 \mathrm{~h}$ ), however they mentioned if the characteristics of wastewater required a large time of

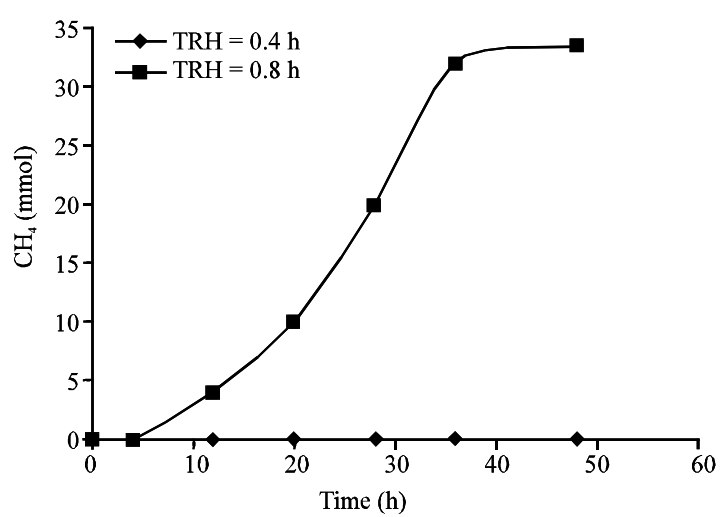

Fig. 5: Methane production (mmol) on a continuous fixed-bed up-flow reactor with Opuntia imbricata as substratum at different HRT's $(0.4$ and $0.8 \mathrm{~h})$ using dairy wastewater (COD $27.73 \mathrm{~g} \mathrm{~L}^{-1}$; initial $\mathrm{pH} 11.32$; temperature $\left.18 \pm 5^{\circ} \mathrm{C}\right)$

hydrolysis, methanogenic activity may not be inhibit if HRT is not short enough. Chen et al. (2001) also mentioned that a shift in $\mathrm{pH}$ from 4.3-6 caused a cease in hydrogen production and only carbon dioxide was produced. These results indicate that a reduction in microbial activity occurs or a shift on the microbial community took place.

Figure 3a also shows that in both HRT cases there was a decrease in hydrogen production as a result of substantial COD consumption (Fig. 4) where at an HRT of $0.8 \mathrm{~h} \mathrm{COD}$ after $36 \mathrm{~h}$ diminish to $11.9 \mathrm{~g} \mathrm{~L}^{-1}$ and for the case of HRT of $0.4 \mathrm{~h}$ it was $17.3 \mathrm{~g} \mathrm{~L}^{-1}$. Early studies on batch showed that hydrogen production was detected at COD concentration over $12 \mathrm{~g} \mathrm{~L}^{-1}$.

Previous studies on batch proved that hydrogen production took place on concentrations of COD higher than $12 \mathrm{~g} \mathrm{~L} \mathrm{~L}^{-1}$, however on concentrations below $12.0 \mathrm{~g} \mathrm{~L}^{-1}$ of $\mathrm{COD}$, methane production is enable leading to a decrease on hydrogen production. This can be observed on (Fig. 4) where removal of COD from $14.8-10.3 \mathrm{~g} \mathrm{~L}^{-1}$ after $60-70 \mathrm{~h}$ at an HRT of $0.4 \mathrm{~h}$ influence the hydrogen production process causing a decrease in hydrogen as mentioned before (Fig. 3a). COD removal efficiency for both cases was $62.34 \%$ after $72 \mathrm{~h}$ and $58.78 \%$ after $48 \mathrm{~h}$ for HRT of 0.4 and $0.8 \mathrm{~h}$, respectably. This concurs with early reports by Lin et al. (2006) in which using high concentration of substrate (glucose 15-25 $\mathrm{g} \mathrm{L}^{-1}$ ) hydrogen production was detected and Kyazze reported hydrogen production even at higher concentrations of substrate using sacarose up to $40 \mathrm{~g} \mathrm{~L}^{-1}$. Figure 5 shows that an HRT of $0.4 \mathrm{~h}$, methanogenic activity was completely inhibit due to fast drop on $\mathrm{pH}$ (4.5-5.0) favoring hydrogen producing bacteria. However, 
in spite of being a short HRT $(0.8 \mathrm{~h})$ and taking in account early reports in which HRT's similar to the those use on this study $(0.5-24 \mathrm{~h})$ in where it was reported a high yield hydrogen production (Wu et al., 2006; Yang et al., 2007) for the case $(0.8 \mathrm{~h})$ it was observed that methanogenic activity was not completely inhibit. This behavior can be explained due the use of biofilms system in which regularly the specific activity is increased and also this type of systems offer a higher operational stability (Qureshi et al., 2005). Also this is mentioned by Wu and Chang (2007) in which the microbial community is protected by the polymeric matrix and allows tolerating extreme environmental conditions.

\section{CONCLUSION}

Results obtained by metagenomic analysis of the microbial mixed culture concluded that the main bacterial microbiota was found to be lactic acid bacteria of Firmicutes phylum. HRT had a strong influence on yield hydrogen production showing that the change of HRT from 0.8-0.4 $\mathrm{h}$ enhanced the yield hydrogen production form $1.31 \mathrm{mmol} \mathrm{H}_{2} \mathrm{~g}^{-1}$ CODconsumed to $2.11 \mathrm{mmol} \mathrm{H}_{2} \mathrm{~g}^{-1} \mathrm{COD}$ consumed.

The use of Opuntia imbricata as substratum for biofilm formation enhanced the hydrogen production offering economical and technical advantages over the use of pure culture, avoiding expensive sterilization requirements, extra use of energy for temperature and $\mathrm{pH}$ control.

\section{ACKNOWLEDGEMENTS}

The present research was supported by National Council for Science and Technology of Mexico (CONACTY). We also thank Dr. Rafael A. Rojas Herrera (Facultad de Ingenieria Quimica de la Universidad Autonoma de Yucatan) for his collaboration in molecular analysis as well for his invaluable knowledge that to contribute to the writing of this study.

\section{REFERENCES}

APHA/AWWA/WEF, 1998. Standard Methods for the Examination of Water and Wastewater. 20th Edn., American Public Health Association/American Water Works Association/Water Environment Federation, Washington, DC., USA., ISBN: 0-87553-235-7.

Alalayah, W.M., M.S. Kalil, A.H. Kadhum, J.M. Jahim and N.M. Alaug, 2008. Hydrogen production using Clostridium saccharoperbutylacetonicum N1-4 (ATCC 13564). Int. J. Hydrogen Energy, 33: 7392-7396.
Angelidaki, I., O.T. Sompong, P. Poonsuk and K. Dimitar, 2008. 16S rRNA-targeted probes for specific detection of Thermoanaerobacterium spp., Thermoanaerobacterium thermosaccharolyticum and Caldicellulosiruptor spp. by fluorescent in situ hybridization in biohydrogen producing systems. Int. J. Hydrogen Energy, 33: 6082-6091.

Chen, C.C., C.Y. Lin and J.S. Chang, 2001. Kinetics of hydrogen production with continuous anaerobic cultures utilizing sucrose as the limiting substrate. Applied Microbiol. Biotechnol., 57: 56-64.

Chen, S. and B. Hu, 2007. Pretreatment of methanogenic granules for immobilized hydrogen fermentation. Int. J. Hydrogen Energy, 34: 3266-3273.

Cheong, D.Y. and C.L. Hansen, 2007. Feasibility of hydrogen production in thermophilic mixed fermentation by natural anaerobes. Biores. Technol., 98: 2229-2239.

Chong, M.L., V. Sabaratnam, Y. Shirai and M.A. Hassan, 2009. Biohydrogen production from biomass and industrial wastes by dark fermentation. Int. J. Hydrogen Energy, 34: 3277-3287.

Cole, J.R., B. Chai, R.J. Farris, Q. Wang and S.A. Kulam et al., 2005. The Ribosomal Database Project (RDP-II): Sequences and tools for highthroughput rRNA analysis. Nucleic. Acids Res., 33: D294-D296.

Coppola, S., G. Blaiotta, D. Ercolini and G. Moschetti, 2001. Molecular evaluation of microbial diversity occurring in different types of Mozzarella cheese. J. Applied Microbiol., 90: 414-420.

Ercolini, D., 2004. PCR-DGGE fingerprinting: Novel strategies for detection of microbes in food. $\mathrm{J}$. Microbiol. Methods, 56: 297-314.

Gadhamshetty, V., D. Johnson, N. Nirmalakhandan, G. Smith and S. Deng, 2009. Dark and acidic conditions for fermentative hydrogen production. Int. J. Hydrogen Energy, 34: 821-826.

Hall, T., 2005. BioEdit: Biological sequence alignment Editor written for Windows 95/98/NT/2000/XP. http://www.mbio.ncsu.edu/BioEdit/bioedit.html.

Hovda, M.B., M. Sivertsvik, B.T. Lunestad, G. Lorentzen and J.T. Rosnes, 2007. Characterization of the dominant bacterial population in modified atmosphere packaged farmed halibut (Hippoglossus hippoglossus) based on 16SrDNA-DGGE. Food Microbiol., 24: 362-371.

Hwang, S.J., M.J. Lee and J.H. Song, 2009. Effects of acid Pre-treatment on biohydrogen production and microbial communities during dark fermentation. Biores. Technol., 100: 1491-1493. 
Ilyna, A., P. Huerta-Guel, J.L. Martinez-Hernandez, J. Rodriguez Martinez and A. Gorokhovsky, 2008. Stability and activity of bovine prostaglandin $\mathrm{H}$ synthase immobilized on Opuntia imbricata (coyonoxtle). J. Mol. Catal. B-Enzym., 51: 1-9.

Kalia, V.C. and H.J. Purohit, 2008. Microbial diversity and genomics in aid of bioenergy. J. Ind. Microbiol. Biotechnol., 35: 403-419.

Kim, I.S., M.H. Hwang, N.J. Jang, S.H. Hyun and S.T. Lee, 2003. Effect of low $\mathrm{pH}$ on the activity of hydrogen utilizing methanogen in bio-hydrogen process. Int. J. Hydrogen Energy, 29: 1133-1140.

Lin, C.Y., C.H. Hung, C.H. Chen, W.T. Chung and L.H. Cheng, 2006. Effects of initial cultivation $\mathrm{pH}$ on fermentative hydrogen production from xylose using natural mixed cultures. Process Biochem., 41: 1383-1390.

Maidak, B.L., J.L. Cole, T.G. Lilbum, C.T. Jr. Parker and P.R. Saxman et al., 2001. The RDP-II (Ribosomal Database Project). Nucleic Acids Res., 29: 173-174.

Mohan, S.V., Y.V. Bhaskar, P.M. Krishna, N.C. Rao and V.L. Babu, 2007. Biohydrogen production from chemical wastewater as substrate by selectively enriched anaerobic mixed consortia: Influence of fermentation $\mathrm{pH}$ and substrate composition. Int. J. Hydrogen Energy, 32: 2286-2295.

Nikolic, S., L. Mojovic, M. Rakin and D. Pejin, 2009. Bioethanol production from corn meal by simultaneous enzymatic saccharification and fermentation with immobilized cells of Saccharomyces cerevisiae var. ellipsoideus. Fuel, 88: 1602-1607.

Nixon, K.C., 1999. The Parsimony Ratchet, a new method for rapid parsimony analysis. Cladistics, 15: 407-414.

Qureshi, N., B.A. Annous, T.C. Ezeji, P. Karcher and I.A. Maddox, 2005. Biofilm reactors for industrial bioconversion processes: Employing potential of enhanced reaction rates. Microbial Cell Factories, 4: 24-24.

Ren, Y., J. Wang, Z. Liu, Y. Ren and G. Li, 2009. Hydrogen production from the monomeric sugars hydrolyzed from hemicellulose by Enterobacter aerogenes. Renewable Energy, 34: 2774-2779.
Rojas, H.R., Z.J. Narváez, M.N. Zamudio and M.ME. Mena, 2008. A simple silica-based method for metagenomic DNA extraction from soils and sediments. Mol. Biotechnol., 40: 13-17.

Sparling, R., D.B. Levin, R. Islam and N. Cicek, 2006. Hydrogen production by Clostridium thermocellum. 27045 from cellulosic biomass substrates. Int. J. Hydrogen Energy, 31: 1496-1503.

Wang, X., P.T. Monis, C.P. Saint and B. Jin, 2009a. Biochemical kinetics of fermentative hydrogen production by Clostridium butyricum W5. Int. J. Hydrogen Energy, 34: 791-798.

Wang, A., L. Gao, N. Ren, J. Xu and C. Liu, 2009b. Biohydrogen production from cellulose by sequential coculture of cellulosic hydrogen bacteria of Enterococcus gallinarum G1 and Ethanoigenens harbinense B49. Biotechnol. Lett., 31: 1321-1326.

Wang, J. and W. Wan, 2009. Experimental design methods for fermentative hydrogen production: A review. Int. J. Hydrogen Energy, 34: 235-244.

Wang, Q., G.M. Garrity, J.M. Tiedje and J.R. Cole, 2007. Naïve Bayesian classifier for rapid assignment of rRNA sequences into the new bacterial taxonomy Applied Environ. Microbiol., 73: 5261-5267.

Wu, J.H. and C.Y. Lin, 2004. Biohydrogen production by mesophilic fermentation of food wastewater. Water Sci. Technol., 49: 223-228.

$\mathrm{Wu}, \mathrm{K} . J$. and J.S. Chang, 2007. Batch and continuos fermentative production of hydrogen with anaerobic sludge entrapped in a composite polymeric matrix. Process Biochem., 42: 279-284.

Wu, S.Y., C.H. Hung, C.N. Lin, H.W. Chen, A.S. Lee and J.S. Chang, 2006. Fermentative hydrogen production and bacterial community structure in high-rate anaerobic bioreactors containing silicone-immobilized and self-flocculated sludge. Biotechnol. Bioeng., 93: 934-946.

Yang, P., R. Zhang, J. McGarvey and J. Benemann, 2007. Biohydrogen production from cheese processing wastewater by anaerobic fermentation using microbial communities. Int. J. Hydrogen Energy, 32: 4761-4771. 